\title{
Chemical and Biochemical Evaluation of Marine Pollution by Polychlorinated Biphenyls and Pesticides in Two Regions Along the Egyptian Mediterranean Sea
}

\author{
Mohamed Atia Sheradah", *, Amany Ahamed El-Sikaily ${ }^{1}$, Nehad Mohamed Abd El Moneam², \\ Nabila Elsayed Abd El Maguid², Marwa Gaber Zaki ${ }^{1}$ \\ ${ }^{1}$ Marine Chemistry and Marine Pollution Research Lab, National Institute of Oceanography \& Fisheries, Alexandria, Egypt \\ ${ }^{2}$ Biochemistry and Zoology Department, Faculty of Science, Alexandria University, Alexandria, Egypt
}

Email address:

niof.shreadah@gmail.com (M. A. Sheradah)

${ }^{*}$ Corresponding author

To cite this article:

Mohamed Atia Sheradah, Amany Ahamed El-Sikaily, Nehad Mohamed Abd El Moneam, Nabila Elsayed Abd El Maguid, Marwa Gaber Zaki. Chemical and Biochemical Evaluation of Marine Pollution by Polychlorinated Biphenyls and Pesticides in Two Regions Along the Egyptian Mediterranean Sea. International Journal of Environmental Monitoring and Analysis. Vol. 6, No. 3, 2018, pp. 95-109. doi: $10.11648 /$ j.ijema.20180603.14

Received: August 1, 2018; Accepted: September 3, 2018; Published: September 26, 2018

\begin{abstract}
The main objective of this paper is to understand the importance of biochemical biomarkers in assessing marine pollution by Polychlorinated biphenyls (PCBs) and Pesticides. Methods: The oxidative stress and antioxidant response as well as ultrastructural changes of both liver and muscle tissues of Siganusrivulatus collected from El-Mex Bay as a polluted region and Marsa Matrouh as a control region far from land-based sources of pollution have been investigated by using standard methods. In general, the results cleared out that El-Mex Bay was much more polluted by polychlorinated biphenyls (PCBs) and pesticides compared to Matrouh area. The concentration range of total polychlorinated biphenyls (PCBs) and pesticides in sediment samples collected from Matrouh coast was 16.29-32.58 ng/g, dry weight and 107.62-149.11ng/g, dry weight, respectively. On contrast, the range in sediment samples collected from El- Mex Bay was 217.12-255.33 ng/g, dry weight and $663.73-778.7 \mathrm{ng} / \mathrm{g}$, dry weight, respectively. Biomarkers studies revealed that the induction of antioxidant systems in response to oxidative stress and the increase in lipid peroxidation in fish collected from the polluted area were good indicators for the pollution load" in the present study. On the meantime, the present study revealed that ultrastructural changes serve as a biomarker of stress in aquatic environment. Moreover, the results suggested that chemical pollution, on the other hand, is capable of inducing morphological alteration in liver of fish collected from polluted area.
\end{abstract}

Keywords: Antioxidant System, Lipid Peroxidation, Ultrastructural Changes, Marine Pollution

\section{Introduction}

The marine environment of Egypt, especially coastal ecosystems has been subjected to a substantial increase in the last decades of pollution due to a great number of industrial, agricultural, commercial and domestic waste, effluents and emissions as well as hazardous substances [1-16]. Because environmental contaminants can have a broad spectrum of sub lethal effects on organisms, so bio-indicators are useful tools for assessing the presence and levels of chemical pollution. Such effects in organisms sensitive to contaminant exposures can be used as early warning signs for the degradation of the environment [17-20].

PCBs are persistent in the environment and accumulate in soils, marine sediments, seawater, sewage sludge and vegetation as well as the fatty tissues of animals [21-23].

By negatively affecting microorganisms, pollutants in aquatic systems may have detrimental effects on higher trophic levels and disrupt the balance of the ecosystem [2429]. Pollutants accumulated in tissues of fish may catalyze reactions that generate reactive oxygen species (ROS) which may lead to environmental oxidative stress. Indicators of oxidative stress include changes in antioxidant enzyme activity, damaged DNA bases, protein oxidation products, 
and lipid peroxidation products [30]. Disturbance of living processes at the molecular and subcellular levels of biological organization by xenobiotics can lead to cell injury, resulting in degenerative and neoplastic diseases in target organs. Therefore histopathological biomarkers have been proven to be useful indicators of toxicity in fish organs [31].

This paper is devoted to investigate the oxidative stress and antioxidant response as well as ultrastructural changes of both liver and muscle tissues of Siganus rivulatus collected from Matrouh area wich is located in the north-western Mediterranean coast of Egypt $290 \mathrm{~km}$ west of Alexandria as a protected area far from land-based sources of pollution and from El- Mex Bay located west of Alexandria which is a highly polluted area [32-41].

\section{Materials and Methods}

\subsection{Methodology}

\subsubsection{Morphological Study}

Siganus rivulatu fish species were collected from El- Mex Bay and Matrouh coast. About 100 fish of similar weight $(30-40 \mathrm{~g})$ were collected from each area. Siganus rivulatu fish samples were dissected. Then livers and muscles were taken and prepared for electron microscopic studies. The remaining livers and muscle tissues were kept frozen at $-20^{\circ} \mathrm{C}$ until use. Fish liver samples were weighted to the nearest milligrams and their hepato-somatic index (HIS, liver weight/body weight $\mathrm{x} 100$ ) was calculated according to Jangaard et al. [42]. Morphological features of Siganus rivulatus in addition to weight and length of Siganus rivulatus collected from both areas were taken. The hepato-somatic index (HIS=liver weight/body weight $\mathrm{x} 100$ ) of fish was calculated.

\subsubsection{Chemical Analysis}

Pesticides and PCBs have been determined in fish according to UNEP/IOC/IAEA [43]. To control the analytical reliability and assure recovery efficiency and accuracy of the results, four analyses were conducted on organochlorine compounds reference material, HS-5 (sediment) provided by NRC-IMB of Canada and SRM-2974 freez-dried muscle tissue (Mytilusedulis) provided by EIMP-IAEA USA. The laboratory results showed recovery efficiency ranged from 95-105\% for pesticides reference material No. 2974 (provided by EIMP/IAEA) with coefficient of variation of $15-20 \%$ for all pesticide congeners.

\subsubsection{Preparation of Tissue Homogenate for Biochemical Analysis}

Prior to dissection, liver tissue was perfused with a (phosphate buffer saline solution, $\mathrm{pH} 7.4$ (PBS), containing $0.16 \mathrm{mg} / \mathrm{ml}$ heparin to remove any red blood cells. The tissue was homogenized in 5-10 $\mathrm{ml}$ cold buffer $(100 \mathrm{mM}$ potassium phosphate, $\mathrm{pH} 7.0$, containing $2 \mathrm{mM} \mathrm{EDTA} / \mathrm{g}$ tissue, and then centrifuge at $10000 \mathrm{xg}$ for $15 \mathrm{~min}$. at $4^{\circ} \mathrm{C}$. The supernatant was removed for assay. The biodiagnostic Glutathione S- transferase assay kit (CAT. No. GT 25 19) is used to measures total Glutathione S-Transferase activity
[44]. Reduced Glutathione (GSH) concentration is determined by Biodiagnostic Gltathione reduced kit (CAT. No. GR 2511) [45].

\subsubsection{Microscopic Study}

Ultra-thin sections $(50 \mathrm{~nm})$ were cut using LKB ultra tome with a glass knife, mounted on copper grids. Semi thin sections $(1 \mu \mathrm{m})$ were also cut from the sample blocks, stained with toluidine blue, and examined under a light microscope. Ultra-thin sections were double stained with freshly prepared uranyl acetate [46] for 20 minutes as well as lead citrate for 5 minutes, and scoping grids was achieved by using JEOL 100CX transmission electron microscope.

\subsection{Statistical Analysis}

This study was statistically analyzed using SPSS (version 10). A difference is considered as significant at $\mathrm{P}<0.05$.

\section{Results and Discussion}

\subsection{Morphological Study}

The morphological study showed that the weight and length range for Siganus rivulatus collected from El-Mex Bay which is a polluted marine environment [32-40] and Marsa Matrouh as a control region were relatively similar, but the hepatosomatic index for siganus rivulatus collected from El- Mex Bay was 2 fold more than those from Matrouh coast (Figure 1). Statistical analysis of data revealed a highly significant difference between the two investigated areas, i.e. El-Mex area and Matrouh area at $\mathrm{p}<0.05$.

\subsection{Chemical Analysis}

The concentration range of total pesticides in fish muscles collected from Matrouh coast is 46.837-66.165 ng/g, dry weight, where this range in fish muscles collected from ElMex bay is 347.11-412.6 ng/g, dry weight. The concentration of total pesticides in fish muscles collected from El-Mex Bay is 7 fold more than those collected from Matrouh coast (Figure 2).

The concentration range of total $\mathrm{PCBs}$ in fish muscles collected from Matrouh coast is $2.19-6.43 \mathrm{ng} / \mathrm{g}$, dry weight, where this range in fish muscles collected from El- Mex Bay is $38.33-57.52 \mathrm{ng} / \mathrm{g}$, dry weight.The concentration of total PCBs in fish muscles collected from El- Mex Bay is 11.5 fold more than those collected from Matrouh coast (Figure 3).

On the same manner, PCBs represent an important group of POPs, which are believed to be possible carcinogens or mutagens as well as endocrine disruptors [47, 48]. PCBs are used in many industrial processes, for example, in dielectric fluids for transformers and capacitors. Barakat et al., [43]. River run off is thought to be one of the major sources of PCBs to the marine environment. Due to their hydrophobic nature, PCBs have strong affinity for particulate material in aquatic ecosystem [48]. 


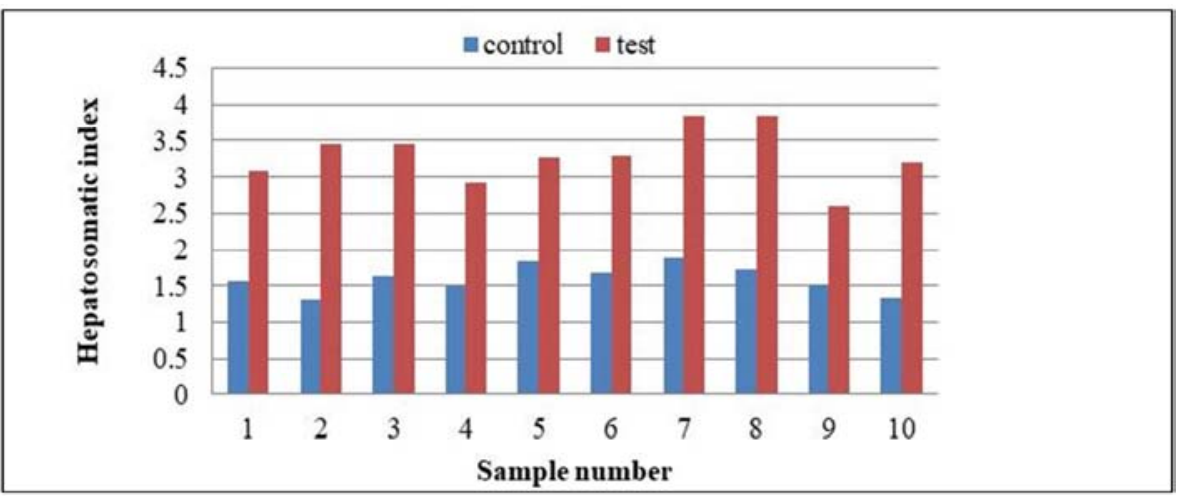

Figure 1. Hepatosomatic index of "Siganus rivulatus" collected from El-Mex Bay compared to Matrouh coast.

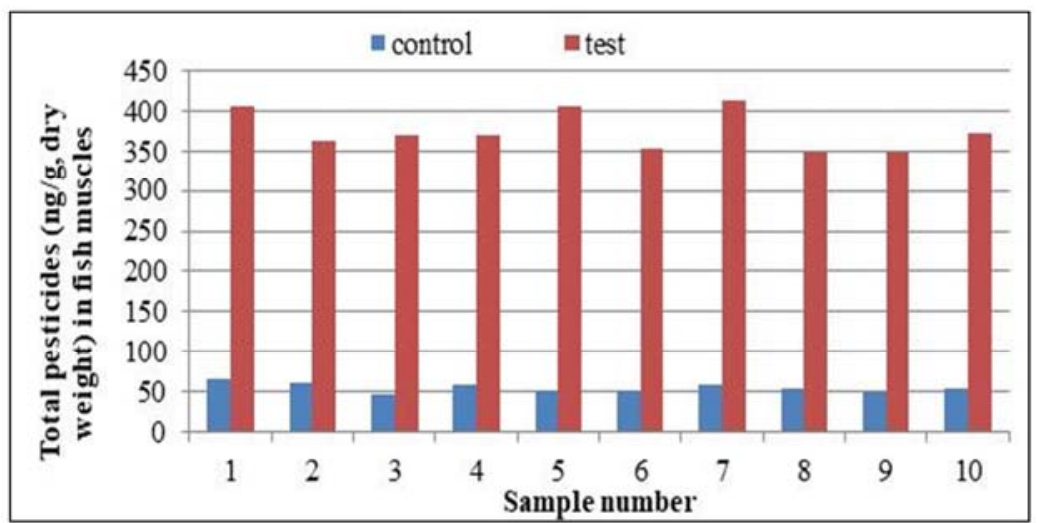

Figure 2. Total pesticide concentration (ng/g; dry weight) of fish muscles collected from El-Mex Bay compared to that of Matrouh Coast.

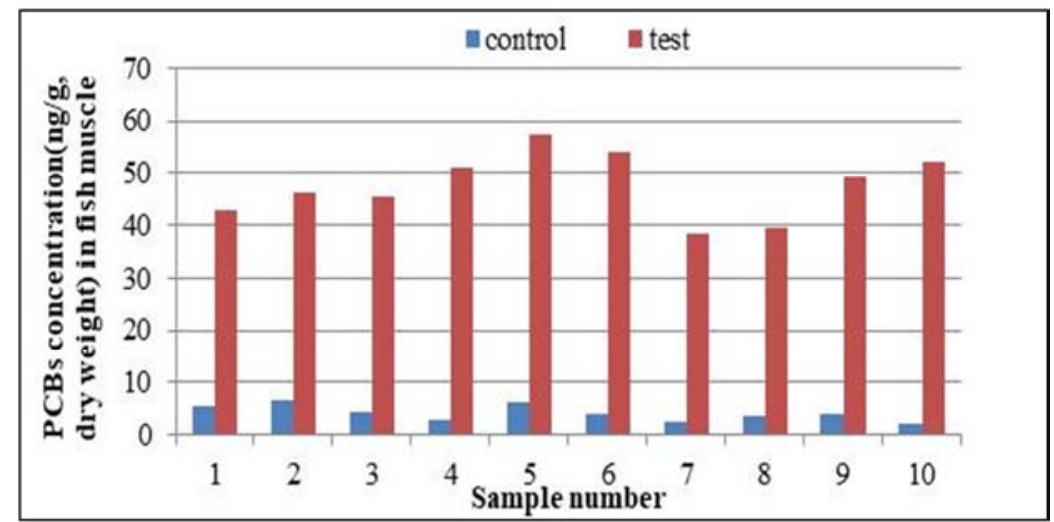

Figure 3. Total PCBs concentrations (ng/g; dry weight) of fish muscles collected from El-Mex Bay compared to that of Matrouh Coast.

The present results for the concentration levels of the investigated PCBs congeners in "Siganus rivulatus" samples collected from Matrouh coast and El-Mex Bay revealed that the concentration range of total PCBs in "Siganus rivulatus" muscles collected from Matrouh coast is $2.19-6.43 \mathrm{ng} / \mathrm{g}$, dry weight, while its range in "Siganus rivulatus" muscles collected from El- Mex Bay is 38.33-57.52 ng/g, dry weight, which is 11.5 fold more than those collected from Matrouh coast. Among the PCBs congeners PCB 52, 118, 138 and 153 were found dominant in both investigated areas, i.e. Matrouh and El-Mex Bay. Chlorination of organic chemicals often increases both their persistence and their lipid solubility. Therefore, PCBs bioaccumulation with increasing number of chlorines increases both lipid solubility and bioaccumulation. However, the optimal bioaccumulation capacity is at about 6 chlorines, probably because higher chlorinated congeners (esp. octa-) are so poorly water soluble so that their bioavailability is low $[49,50] . \alpha, \beta-\mathrm{HCH}$ residues were found at high concentration in Siganus rivulatus muscle samples collected from El-Mex Bay with an average of 28.31 and $28.46 \mathrm{ng} / \mathrm{g}$, dry weight, respectively and are much more than their corresponding values for fish collected from Matrouh coast (2.183 and $5.96 \mathrm{ng} / \mathrm{g}$, dry weight, respectively). High concentrations of $\gamma-\mathrm{HCH}$, hepatochlor, aldrin, endrine and dieldrine are also present in high concentrations in Siganus rivulatus muscle samples collected 
from El-Mex Bay compared to their corresponding values for Siganus rivulatus collected from Matrouh coast. P, P'-DDD, P, P'-DDE, P, P'-DDT residues were measured in Siganus rivulatus muscles collected from El-Mex Bay (87.66, 33.39, $15.76 \mathrm{ng} / \mathrm{g}$, dry weight, respectively) in higher concentrations compared to their corresponding values for fish collected from Matrouh coast (13.53, 11.44, $1.96 \mathrm{ng} / \mathrm{g}$, dry weight, respectively). The present study showed that total cyclodienes followed by DDTs and then hexachlorocyclohexane (176.97, 136.71, $79.26 \mathrm{ng} / \mathrm{g}$, dry weight, respectively) are dominate in El-Mex Bay followed by DDTs, cyclodienes and HCHs $(26.94,18.96,9.57 \mathrm{ng} / \mathrm{g}$, dry weight, respectively). The results indicated the presence of Aldrin in high concentrations in Siganus rivulatus compared to their corresponding values from Matrouh coast. Our finding is in agreement with the work of Said and Abdel Fattah [51] who proved that Aldrin (alicyclic chlorinated hydrocarbon) less resistant to oxidation than the aromatics. It is being rapidly converted to epoxide form (dieldrin). The author also reported that the average concentrations of DDT are elevated which generally used against a wide variety of agricultural and forest pests and against insect pests including vectors such as mosquito and tse tse fly. In the environment, DDT can be degraded by solar radiation or metabolized in micro-organisms. In 1989 WHO proved that dehydrochlorination of DDT gives the metabolite DDE. This may be the cause of the presence of high concentration of DDE in El-Mex Bay and Matrouh coast than DDTs. It could be also due to higher vapour pressures of HCHs than DDTs which facilitate relatively rapid atmospheric dissipation in the tropics, leaving fewer residues in soil and water [52]. According to the results of GESAMP [53] the use of HCHs in agriculture is greater than cyclodiens and DDTs. The relatively low concentrations of $\mathrm{HCHs}$ in fish tissues of the present study reflected their lower potential for bioaccumulation than other congener's pesticides. The concentrations of DDD (metabolite form of DDT) represents the major part of all measured DDTs, suggesting that metabolic transformation of DDT under oxidative conditions will lead to p,p-DDD which is detected in large percentage $(64 \%)$ of all DDTs values.

\subsection{Biochemical Analysis}

Contamination of water with industrial and agricultural pollutants influences the biochemical processes of aquatic organisms [54]. An effective monitoring system using biochemical markers has been established to demonstrate these xenobiotics in the environment. On the other hand, the evaluation of oxidative stress is commonly used in monitoring programs based on measurements of catalyze (CAT), glutathione peroxidase (GPX) and superoxide dismutase (SOD) activities [55-57]. The generation of oxyradicals has a connection to the etiology of several human diseases and is probably the same for fish [58]. The statistical analysis of liver and muscle glutathione s-transferase revealed that there was a highly significant increase in liver and muscle glutathione s-transferase activity and glutathione concentration of Siganus rivulatus collected from El- Mex Bay than those collected from Matrouh coast at $\mathrm{p}<0.05$. Liver and muscle glutathione s-transferase activity of Siganus rivulatus collected from El-Mex Bay increased by $107.21 \%$ and $63.41 \%$, respectively, compared to those collected from Matrouh coast as shown in Figures (4 \& 5), respectively. Apart from the normal metabolism in a living organism; carcinogens (pesticides, heavy metals), infections (bacterial, parasitical, viral), radiation damage, and environmental stress factors cause an increase in free oxygen radicals and thus cause oxidative stress [59]. Recent findings showed also that the pollution toxicity in an aquatic organism may be connected to increased production of reactive oxygen species (ROS) that leads to oxidative stress $[60,61]$. In this respect, a number of studies confirmed the successful role of antioxidant enzymes and non-enzymatic antioxidant modulation in identifying environmental stress [62].

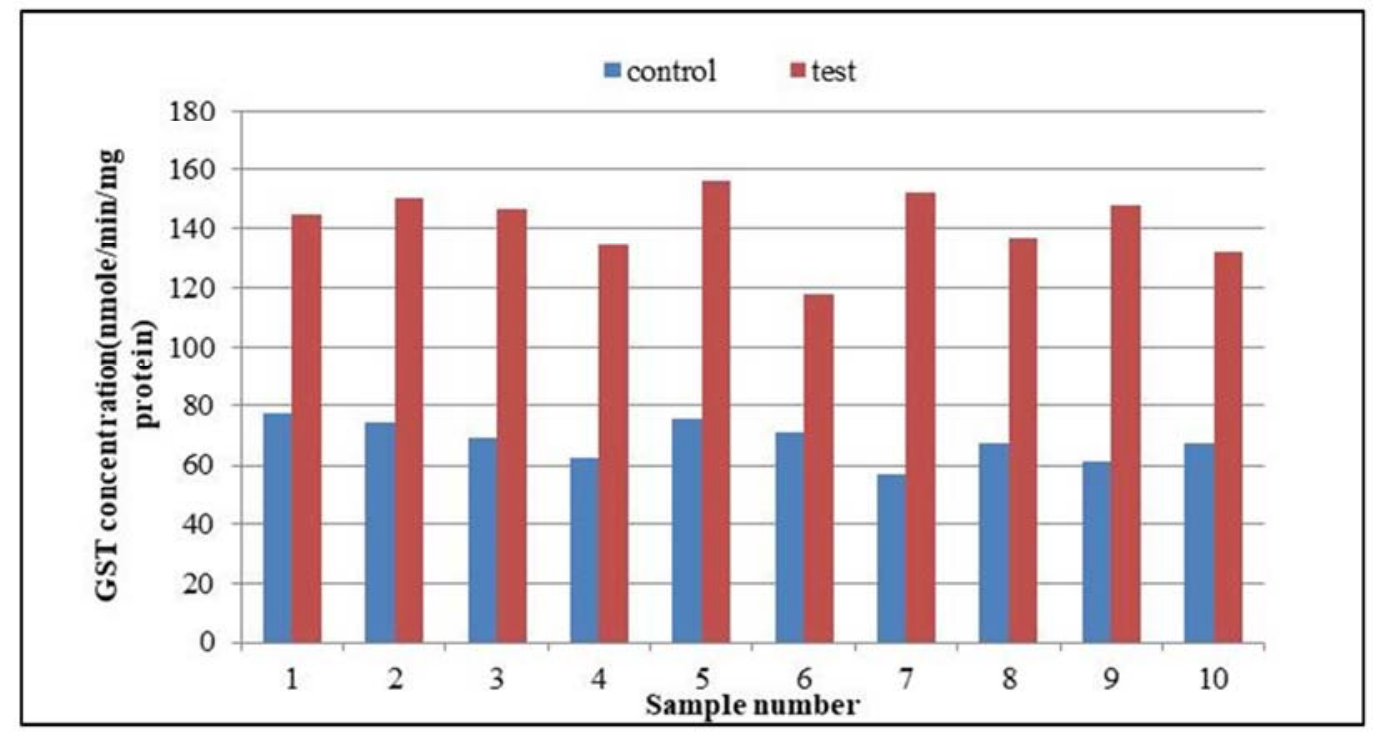

Figure 4. Liver glutathione s-transferase activity of "Siganusrivulatus" collected from El-Mex Bay compared to Matrouh coast. 


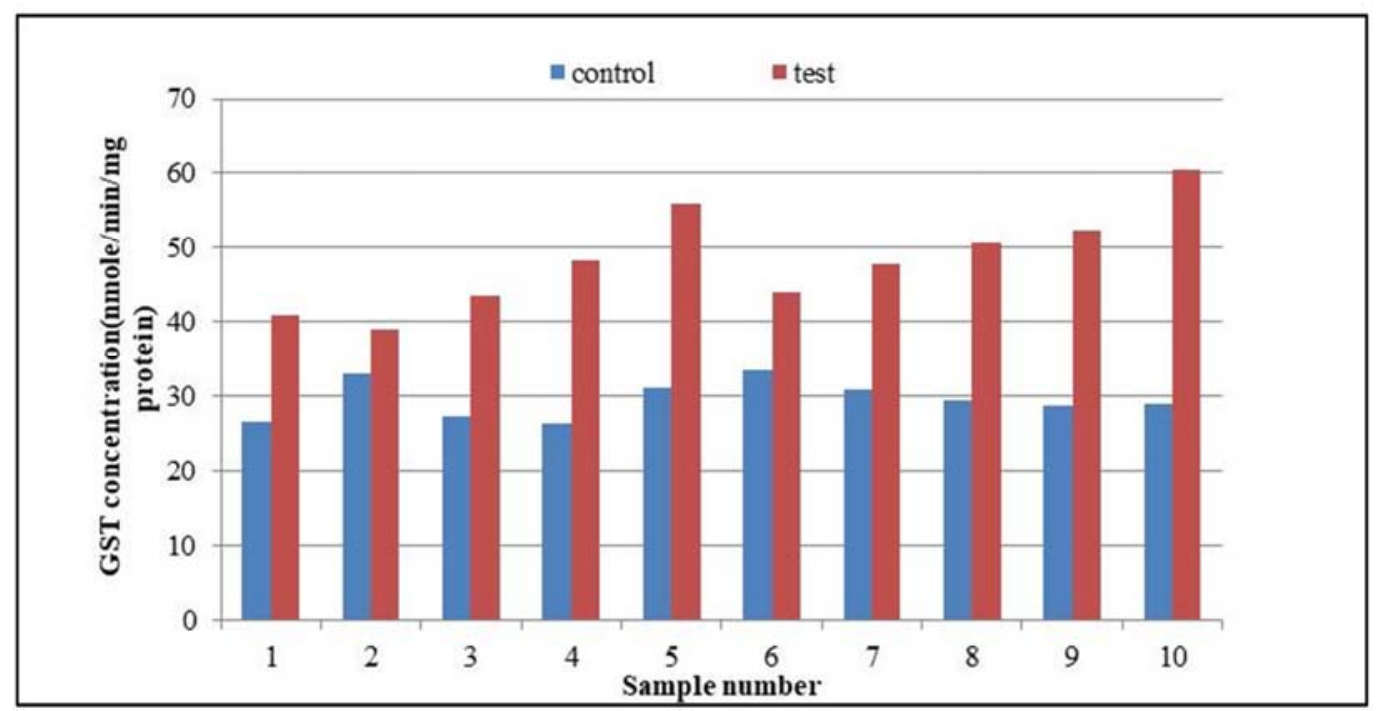

Figure 5. Muscle glutathione s-transferase activity of "Siganusrivulatus" collected from El-Mex Bay compared to Matrouh coast.

In addition, lipid peroxidation estimation in particular has also been found to have a high predictive importance as a biomarker of exposure [63-65]. Therefore, this study aimed to detect the oxidation stress response in liver and muscle of Siganus rivulatus collected from El-Mex bay and Matrouh to identify the significance of oxidative biomarkers as an early indicator of the health of marine ecosystem. An important liver biomarkers used for environmental pollution are glutathione S-transferase (GST) enzyme and glutathione in its reduced form (GSH) [53]. The presence of organic pollutants in fish muscle and their relation to specific biomarkers were also determined by Siroka et al. [66] where, the GST is an important intracellular enzyme of the second stage of xenobiotic metabolism. Its main function is to catalyze the conjugation of glutathione and electrophilic substances of exogenous origin that might be one of etiological factors of carcinogenesis and development of degenerative diseases [67].It is used as a biochemical marker of aquatic environmental contamination with exogenous substances [68]. The liver and muscle tripeptide glutathione concentration of Siganusrivulatus collected from El- Mex Bay was increased by $73.63 \%$ and $77.54 \%$, respectively compared to its corresponding value collected from Matrouh coast (Figure 6 and Figure 7, respectively).

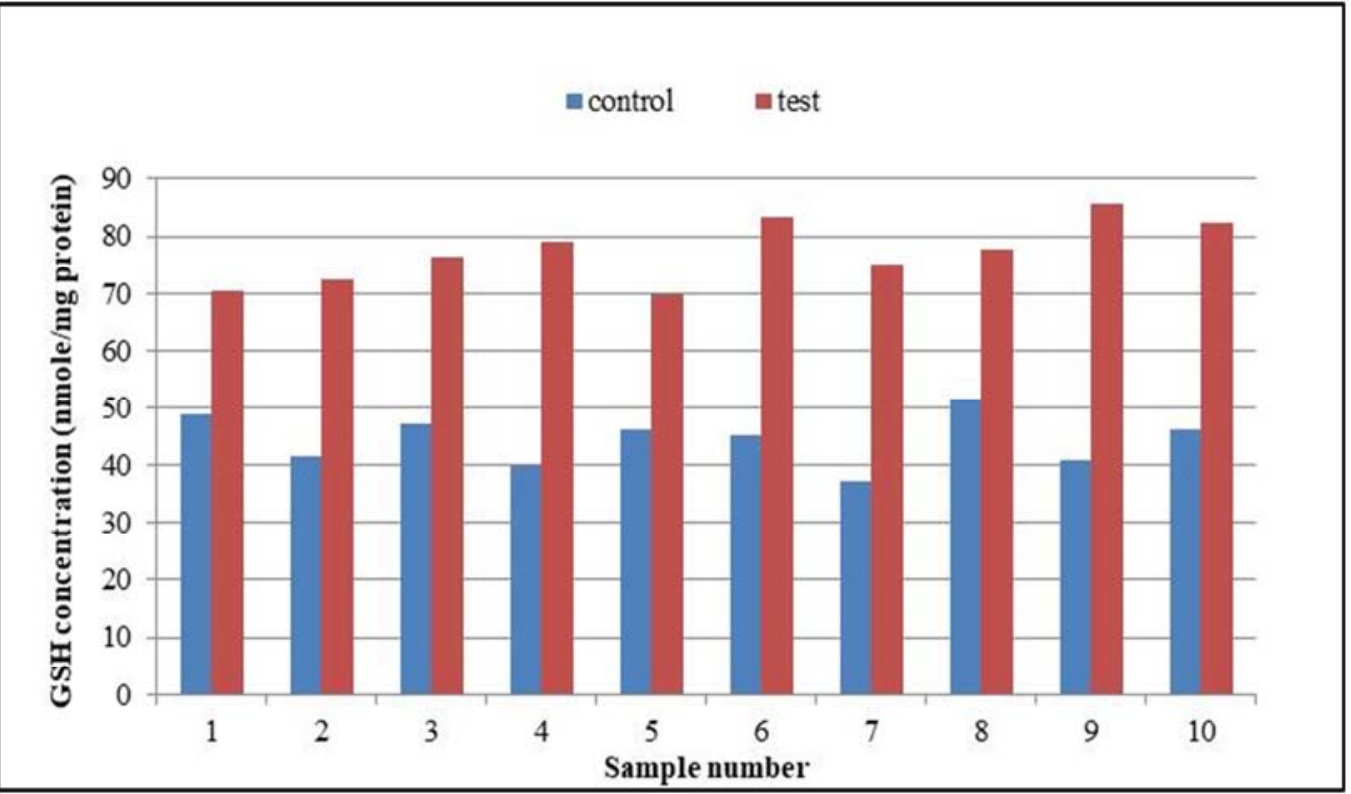

Figure 6. Liver glutathione reduced concentration of "Siganus rivulatus" collected from El-Mex Bay compared to Matrouh coast. 


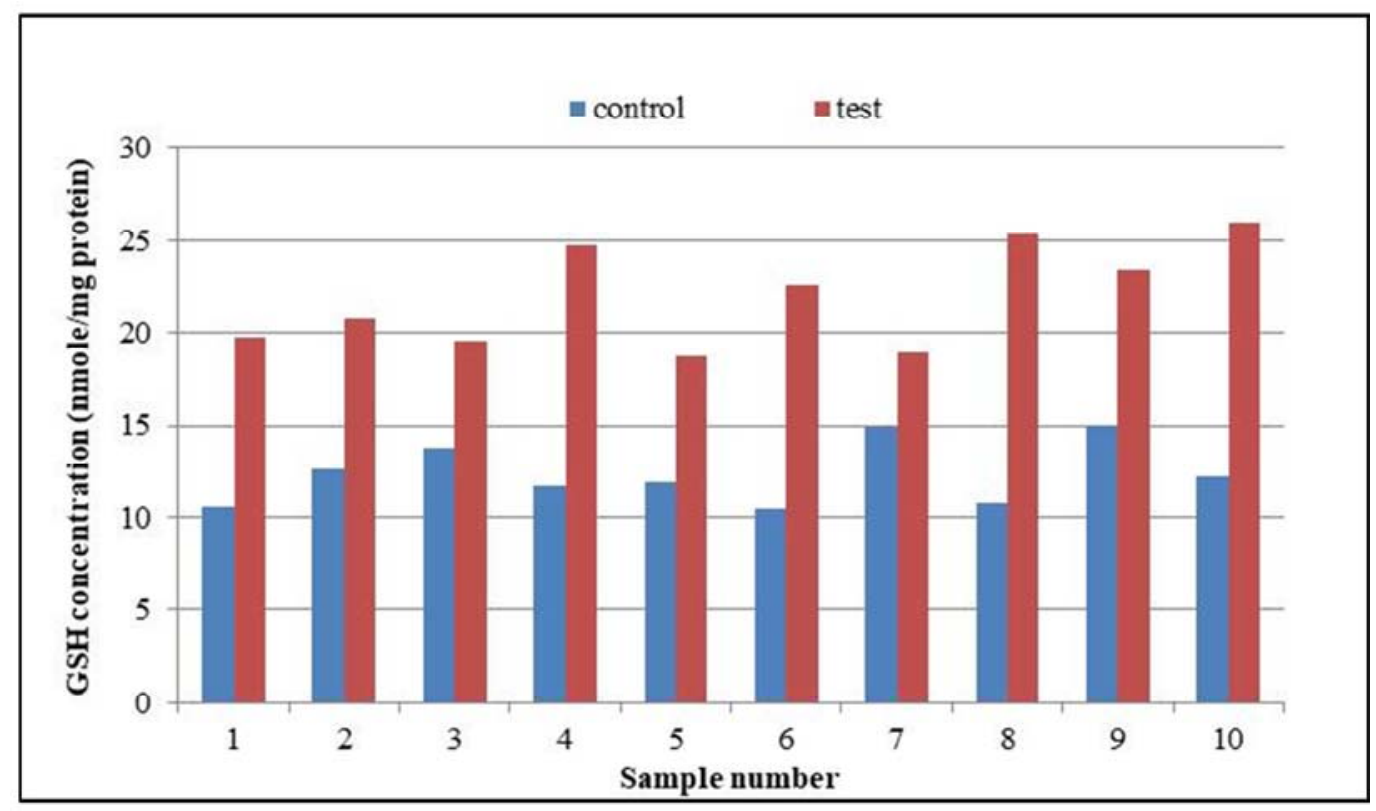

Figure 7. Muscle glutathione reduced concentration of "Siganusrivulatus" collected from El-Mex bay compared to Matrouh coast.

The liver and muscle lipid peroxidation concentration for "Siganus rivulatus" collected from El- Mex Bay increased by $255 \%$ and $176 \%$, respectively, compared to those collected from Matrouh coast (Figure 8 and Figure 9, respectively). Moreover, measurements of lipid peroxidation which has been described as a biomarker for effect of pollution in several studies was also a useful indicator for the pollution load [60]. An elevation of MDA registered the oxidative stress due to the presence of contamination [67]. This study indicated the existence of a significant elevation in liver and muscle lipid peroxidation of "Siganus rivulatus" collected from El-Mex bay compared to that collected from Matrouh coast as shown in Figure (8) and Figure (9). The apparent increase in lipid peroxidation may be attributed to the accumulation of the chemical pollutant in the organs under investigation indicating the existence of significant pollutant concentration in the fish liver and muscle of this area.

Chemical pollutant catalyzes the formation of ROS capable to damage tissues such as DNA, proteins and lipids. The results of this study were in agreement with the work of Farombi et al., [69] who found that the level of MDA activity in the liver of Cat fish (Clariasgariepinus) collected from Ogun River was significantly elevated in all fish organs compared to fishes collected from the Agodi fish farm, the percentage increase in liver, kidney, gills and heart lipid peroxidation were $177 \%, 102 \%, 168 \%$ and $71 \%$ respectively.

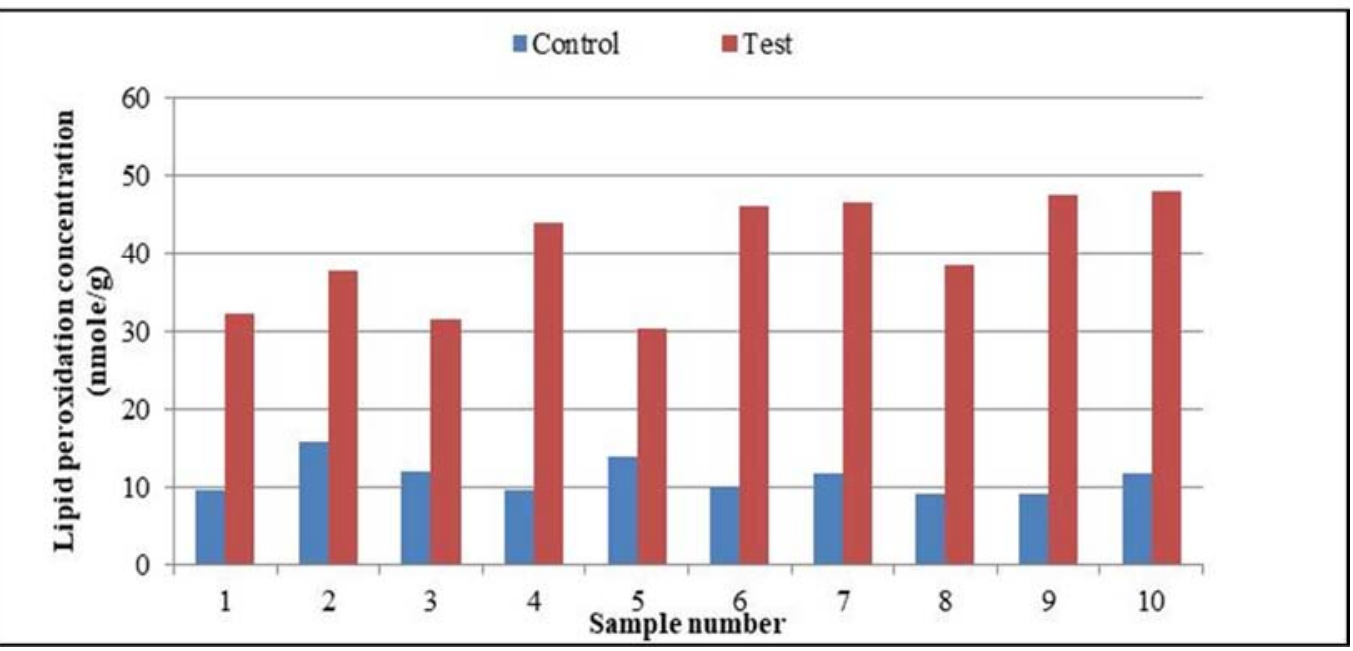

Figure 8. Liver lipid peroxidation concentration (nmole/g) of "Siganus rivulatus" collected from El-Mex Bay compared to Matrouh coast. 


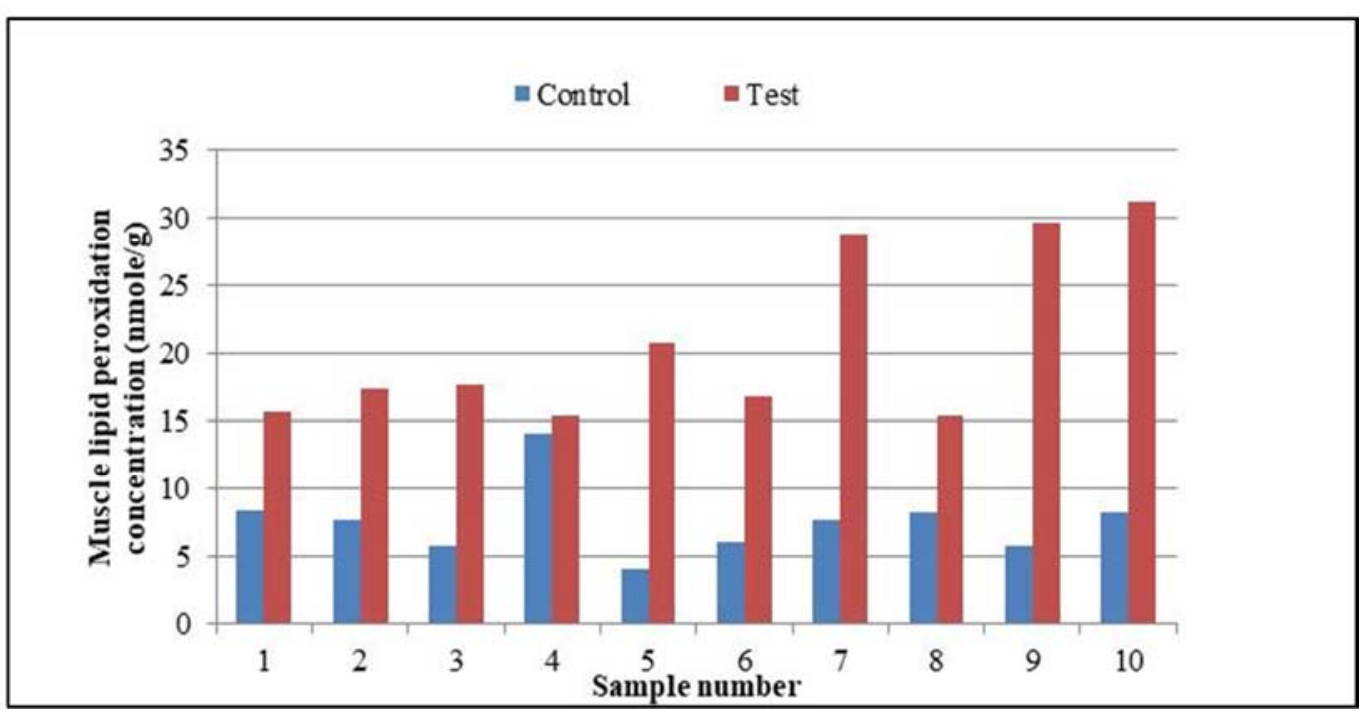

Figure 9. Muscle lipid peroxidation concentration (nmole/g) of "Siganus rivulatus" collected from El-Mex Bay compared to Matrouh coast.

\subsection{Microscopic Observations}

\subsubsection{Microscopic Observation of Hepatocytes}

a. Microscopic structure of liver specimens of Siganus rivulatus from Matrouh coast

Light micrographs of glutaraldehyde fixed $\mathrm{OsO}_{4}$ post fixed toulidine blue stained livers of "Siganus rivulatus" collected from Matrouh coast revealed, normal architecture (Figure 10) including heoatocytes and non-hepatocytes structures. The liver of S. rivulatus composed of masses of hepatocytes not organized into distinct lobules and interrupted by sinusoids. Morphmetric measurements based on light micrographs revealed that the hepatocytes possess a mean length of $7.62 \mu \mathrm{m}$ and a mean width of $4.84 \mu \mathrm{m}$. These polyhedral shaped cells housed spherical central nuclei and moderately eosinophilic granular cytoplasm. Light preparations showed that some nuclei have centric nucleoli and some revealed eccentric nucleoli (Figure 10). Blood vessels and bile ducts were randomly observed among the hepatic parenchyma. Few melanomacrophage centers were also found among hepatic parenchyma, and were usually located in the vicinity of blood vessels and bile ducts. Similarly, transmission electron microscopic preparations of Siganus rivulatus collected from Matrouh coast (control area) showed polyhedral hepatocytes, each hepatocyte surrounded by cell boundary which is only visible in electron micrograph i.e. out of resolution of light microscope. Extended layer of organelles were observed around the nucleus and consisting of nearly parallel stacks of rough endoplasmic reticulum (RER) cisternae, smooth endoplasmic reticulum (SER) vesicles, numerous spherical (mean diameter equal $1.2 \mu \mathrm{m}$ ) and avoid mitochondria (with mean length equal $1.8 \mu \mathrm{m}$ and mean width equal $1.4 \mu \mathrm{m}$ ) with short tubular cristae and few lysosomes (Figure 11). Peroxisomes with granular dense matrix and nucleoid were also observed in preparations of this group. Numerous glycogen granules were found accumulated between the organelles of the cytoplasm (Figure 12).

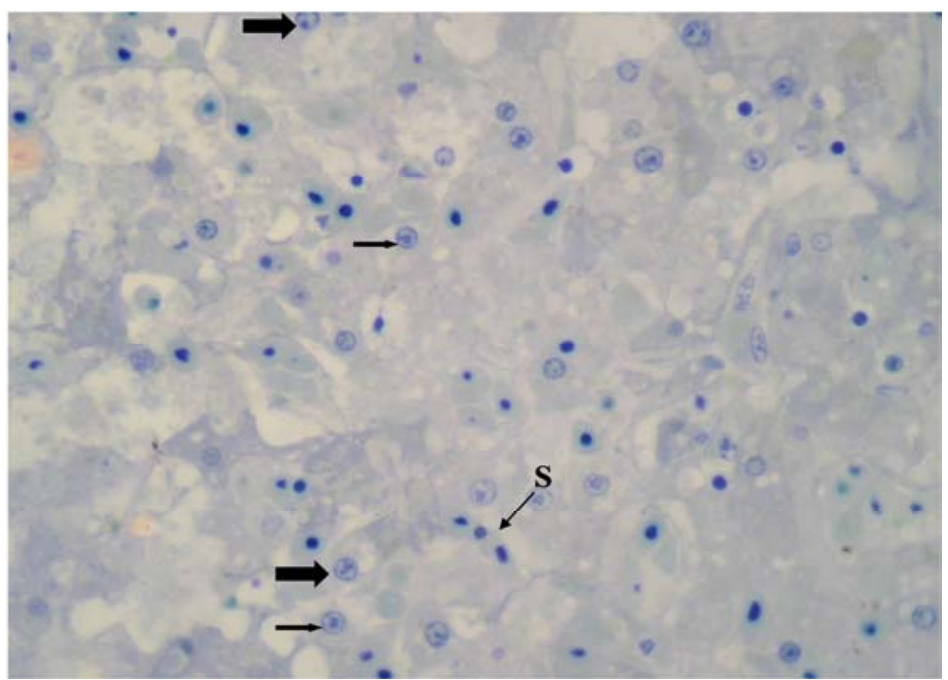

Figure 10. Light micrograph. Semithin section of liver of "Siganus rivulatus" collected from Matrouh coast (control area). Showing, polyheadral shape hepatocytes, spherical shaped nuclei, with moderate chromatin content, some nuclei showed centric nucleoli (thin arrow), other nuclei revealed eccentric nucleoli (thick arrow), blood sinusoids (S) in between hepatocytes [Glutaraldehyde fixed-Os $\mathrm{O}_{4}$ post fixed-toulidine blue-stained preparation X, 1500]. 


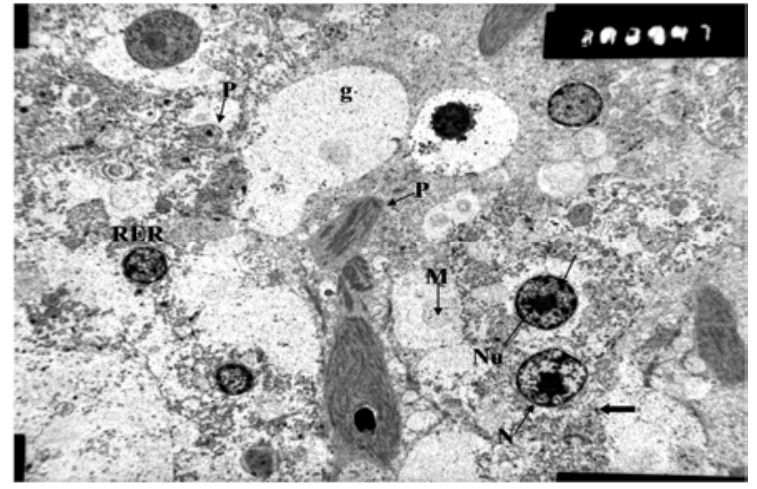

Figure 11. Electron micrograph. Liver section of "Siganus rivulatus" collected from Matrouh coast (control area). Showing, binucleated hepatocytes, spherical nucleus $(N)$ in the central of hepatocyte, some nuclei showed centric nucleoli (thin arrow), some nuclei revealed eccentric nucleoli (thick arrow), the hepatocyte nucleus possessed mostly regular nuclear envelope, small amount of condensed heterochromatin attached with the nucleolus (Nu), rough endoplasmic reticulum (RER), surrounded the nucleus spherical and avoid mitochondria (M) with short tubular cristae, few peroxisomes $(P)$ with granular dense matrix, glycogen stores ( $g$ ) [Glutaraldehyde fixed- $\mathrm{OsO}_{4}$ post fixed-uranyl acetate-lead citrate stained preparation $X, 4500]$.

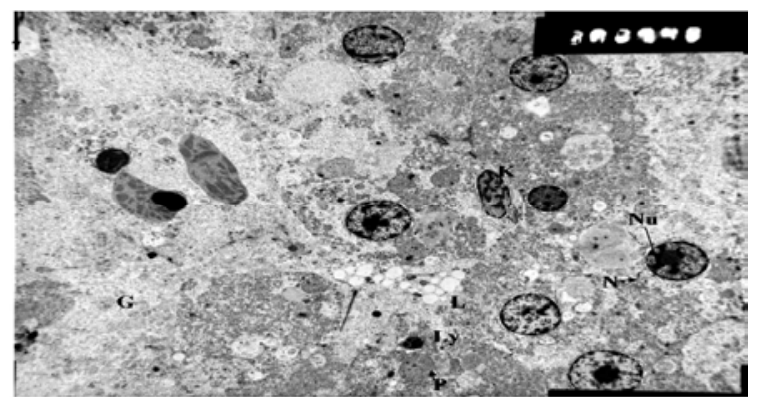

Figure 12. Electron micrograph. Liver section of "Siganus rivulatus" collected from Matrouh coast (control area). Showing, masses of hepatocytes, kuffer cell (K), hepatocytes mononucleated, spherical nucleus (N) in the central of hepatocyte, the hepatocyte nucleus possessed mostly regular nuclear envelope, heterochromatin content attached with the nucleolus $(\mathrm{Nu})$, small number of peroxisomes $(P)$ with granular dense matrix, small number of lysosomes(Ly), small number of lipid droplets $(L)$, glycogen $(G)$. [Glutaraldehyde fixed- $\mathrm{OsO}_{4}$ post fixed-uranyl acetate-lead citrate stained preparation $X, 4500]$

b. Structure of liver specimens of Siganus rivulatus from El-Mex Bay

Microscopic examination of liver sections of "Siganus rivulatus" collected from El-Mex Bay revealed histopathological changes and cellular lesions in comparison with that collected from Matrouh coast (control area). Light micrographs of this group similarly showed that the liver is composed of masses of hepatocytes interrupted by sinusoids. The hepatocytes appear pale and swollen like balloon where large lipid droplets accumulated in their cytoplasm. In addition, pyknotic nuclei were observed in some hepatocyte (Figure 13). The morphometric measurements based on both light and electron micrographs showed that the hepatocyte possesses $10.52 \mu \mathrm{m}$ mean length and $8.36 \mu \mathrm{m}$ mean width on the other hand, the hepatocyte of "Siganus rivulatus" collected from Matrouh coast (control area) possess mean length equal $7.62 \mu \mathrm{m}$ and mean width equal

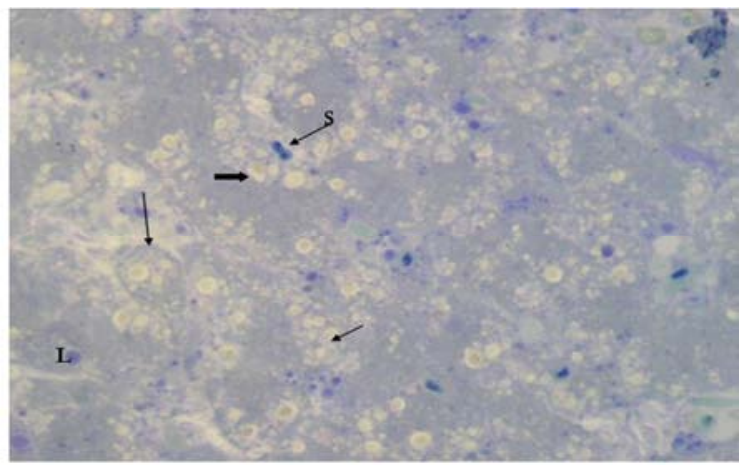

Figure 13. Light micrograph. Semithin section of liver of "Siganus rivulatus" collected from El-Mex Bay (test area). Showing, pale and swollen hepatocytes (thin arrow), pyknotic nuclei (thick arrow), with decreased chromatin content, large number of lipid vaccules (L), blood sinusoids in between hepatocytes (S), sinusoidal congestion [Glutraldehyde fixed-OsO $\mathrm{O}_{4}$ post fixed-toulidine blue-stained preparation X, 1500].

$4.84 \mu \mathrm{m}$. Data analysis using t-test indicated there is a highly significant increase in the hepatocyte length and width in test area comparing to that of control area at $p<0.05$. In addition, nuclei revealed irregular nuclear envelope, their heterochromatin appears as dense patches in nucleoplasm. Endothelial cells and few kuppfer cells line the sinusoidal lumen. Also, examination of electron micrographs of liver sections of "Siganus rivulatus" collected from El-Mex Bay area showed ultrastructural alterations compared to normal appearing hepatocytes. Most hepatocytes were mononucleated, anomalous mitochondria with indistinct membrane were observed, some of which exhibited partial loss of cristea, other exhibited swelling. It is of interest to mention that it is very difficult to distinguish organelles boundary membranes (Figure 14).

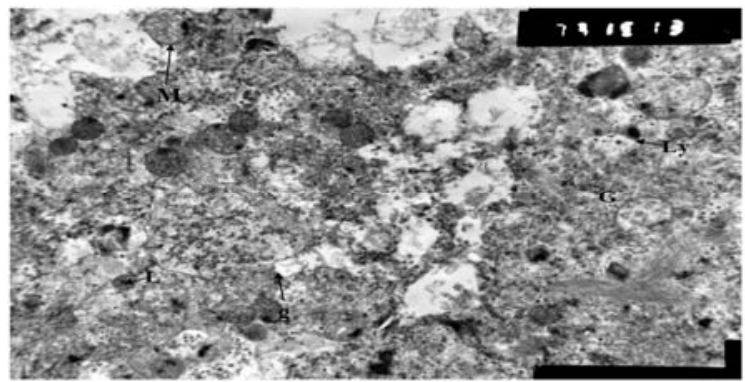

Figure 14. Electron micrograph. Liver section of "Siganus rivulatus" collected from El-Mex Bay (test area). Showing, numerous lysosomes (Ly) different in size and stainability, mitochondria (M), lipid droplets $(L)$, glycogen stores $(g)$, cytoplasm houses a huge amount of glycogen $(G)$ [Glutaraldehyde fixed- $\mathrm{OsO}_{4}$ post fixed-uranyl acetate-lead citrate stained preparation $X, 10500]$.

The most frequently encountered alteration was nuclear pyknosis in addition to irregular nuclear membrane and altered nucleoli (Figure 15). The mean nuclear diameter was found to be $0.7 \mu \mathrm{m}$. Data analysis using student t-test exhibit that there is a highly significant decrease in the nuclear diameter in the test area comparing to that of control area at 
$p<0.05$. Fragmentation and vesiculation of RER cisternae. Additionally an increase in number of primary and secondary lysosomes were noticed as shown in Figure (16). Moreover, preparations of this group showed atrophy and lysis of mitochondria (Figure 17).

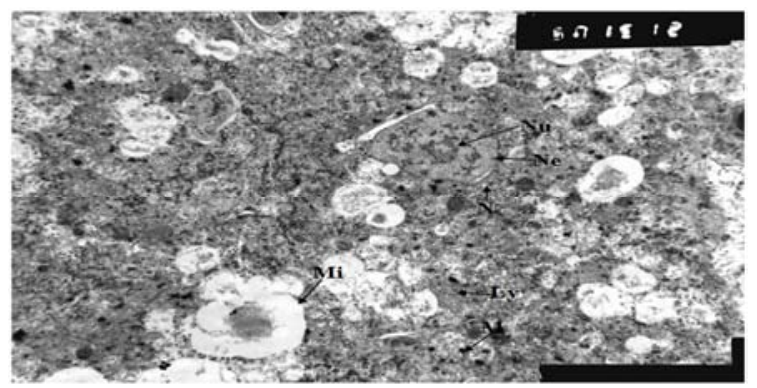

Figure 15. Electron micrographe. Liver section of "Siganus rivulatus" collected from El-Mex Bay (test area). Showing, altered nucleus (N) with irregular nuclear envelope (Ne), segregated nucleolus $(\mathrm{Nu})$, decreased heterochromatin, large number of microbodies (Mi), large number of primary lysosomes (Ly) [Glutaraldehyde fixed- $\mathrm{OsO}_{4}$ post fixed-uranyl acetate-lead citrate stained preparation X, 7500].

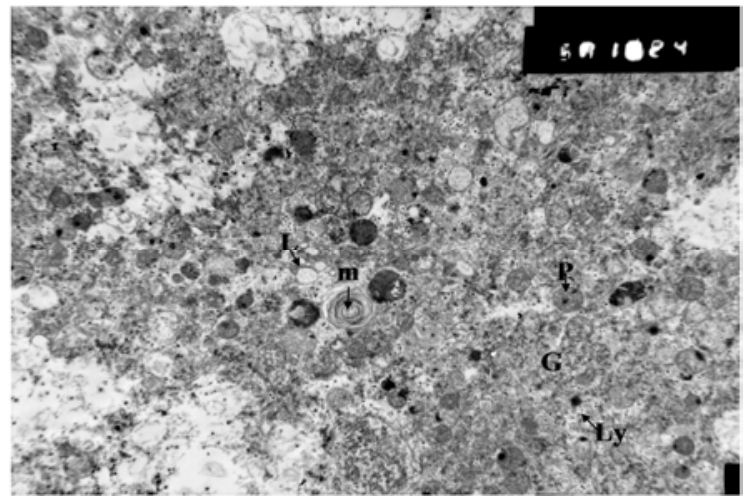

Figure 16. Electron micrograph. Liver section of "Siganus rivulatus" collected from El-Mex Bay (test area). Showing, numerous secondary lysosomes (Ly) different in size and stainability, large number of perixosome $(P)$, myline $(m)$, numerous lipid droplets $(L)$, cytoplasm houses a huge amount of glycogen $(G)$ [Glutaraldehyde fixed- $\mathrm{OsO}_{4}$ post fixed-uranyl acetate-lead citrate stained preparation $X, 7500]$.

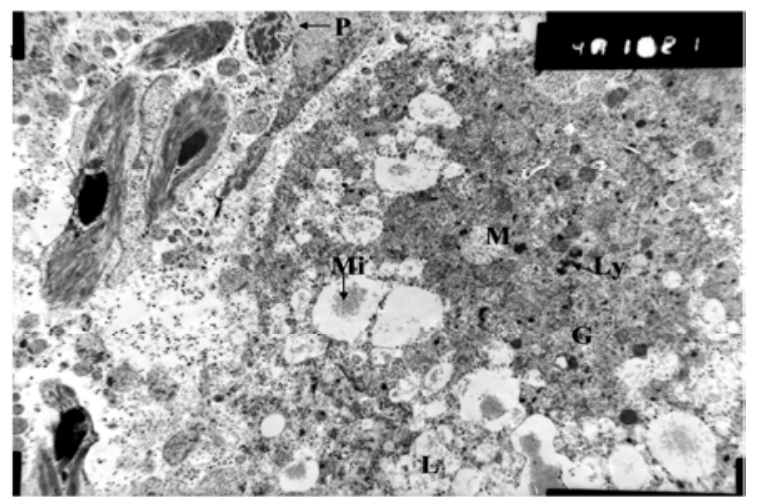

Figure 17. Electron micrograph. Liver section of "Siganus rivulatus" collected from El-Mex Bay (test area). Showing, numerous lysosomes (Ly) different in size and stainability, mitochondria $(M)$, large number of perixosome $(P)$, large number of microbodies (Mi), numerous lipid droplets $(L)$, cytoplasm houses a huge amount of glycogen $(G)$ granules [Glutaraldehyde fixed- $\mathrm{OsO}_{4}$ post fixed-uranyl acetate-lead citrate stained preparation $X, 6000]$.

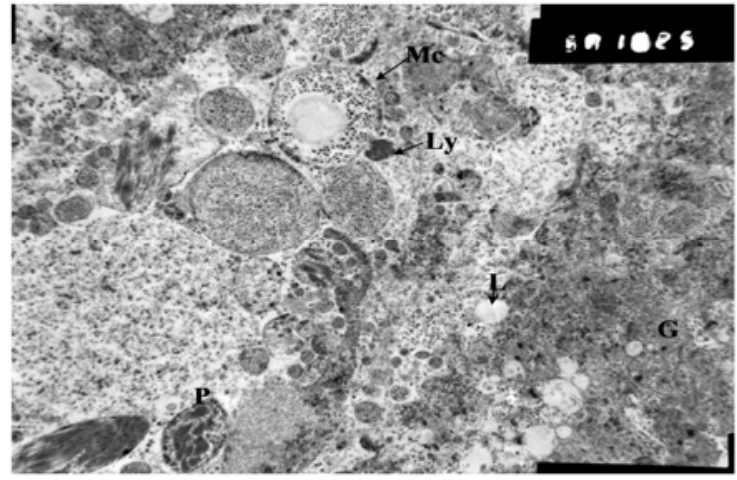

Figure 18. Electron micrograph. Liver section of "Siganus rivulatus" collected from El-Mex Bay (test area). Showing, large size melanomacrophage center (Mc), numerous primary and secondary lysosomes (Ly) different in size and stainability, large number of perixosome $(P)$, numerous lipid droplets (L), cytoplasm houses a huge amount of glycogen $(G)$ [Glutaraldehyde fixed- $\mathrm{OsO}_{4}$ post fixed-uranyl acetate-lead citrate stained preparation $X, 7500]$.

The mitochondrial mean diameter was found to be equal $0.74 \mu \mathrm{m}$. Data analysis using student t-test exhibit that there is a highly significant decrease in the mitochondria diameter in the test area comparing to that of control area at $\mathrm{p}<0.05$. Large empty vacuoles with flocculent materials and myline, large number of perixisome, melano-macrophage centres increase in size and number (Figure 18), increase number of vacuoles containing glycogen stores were also noticed. In addition, the cytoplasm houses an increase of number of microbodies (Figure 19).

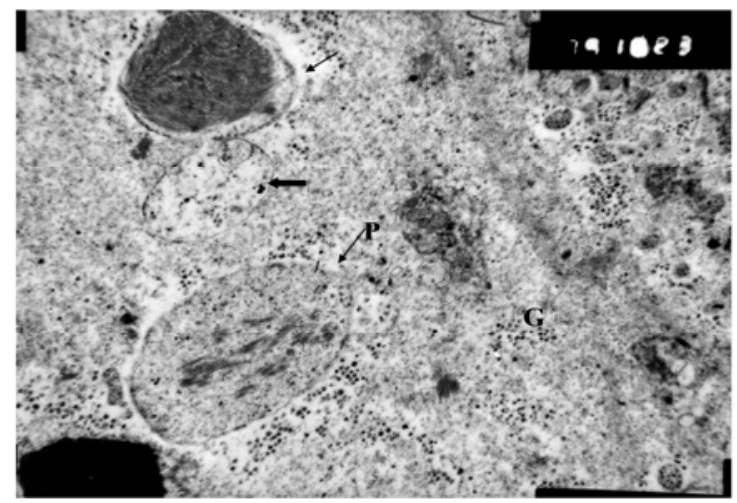

Figure 19. Electron micrograph. Liver section of "Siganus rivulatus" collected from El-Mex Bay (test area). Showing, vacuoles containing dense bodies (thin arrow), vacuoles containing glycogen (thick arrow), perixisome $(P)$ hypertrophied, cytoplasm containing dense glycogen (G) [Glutaraldehyde fixed- $\mathrm{OSO}_{4}$ post fixed-uranyl acetate-lead citrate stained preparation $X, 10500]$.

\subsubsection{Microscopic Observation of Muscle Fiber}

a. Structure of muscle specimens of Siganus rivulatus from Matrouh coast

Light micrographs of muscle fibers of Siganus rivulatus from Matrouh coast revealed normal architecture in comparison to those described in textbooks. The muscle cells were enveloped by sarcolemma, a delicate sheath of connective tissue, the endomysium, and were connected to nerve side branches and blood capillaries. The morphological 
measurement based on light micrographs showed that the muscle cell thickness found to be equal $34.5 \mu \mathrm{m}$.The sarcolemma was identified as a regular outline enclosing the muscle fiber having numerous folds, termed junctional folds. The control muscle fibers were arranged in a strictly ordered cross-striation of alternating brands of light and dark material (Figures $20 \& 21$ ). Electron microscopic preparations of the muscle fibers of Siganus rivulatus, showed that they were composed of sarcoplasm and longitudinal arrays of myofibrils. The center of each dark (A-band or actin) was occupied by a pale area known as H-zone (Hensen's zone) which is bisected by an additional thin striation known as M-line (Mittelsheibe). However, light band (I-band or myosin) was very difficult to distinguish. A thin dark line, known as a Z-line (Zwischenscheibe) bisected the I-band which was relatively thick and distinguished by its density. The average length of the sarcomere (the region between the two successive Z-lines) was about $1.51 \mu \mathrm{m}$. The average length of A-bands was found to be about $1.07 \mu \mathrm{m}$, while the I-bands was found to be equal $0.41 \mu \mathrm{m}$ and the H-zone was found to be $0.12 \mu \mathrm{m}$ (Figure 22). In electron microscopic preparations, the sarcoplasm was differentiated into peripheral sarcoplasm occupied the thin region and the nearest myofibrils, interfibrillar sarcoplasm filled the spaces between myofibrils and perinuclear sarcoplasm which is found at the pole of the nucleus. The sarcoplasm contains non-myofibillar components including nuclei, mitochondria and sarcoplasmic reticulum, in addition to cellular inclusions such as glycogen particles. The nuclei (mean length equal $5.2 \mu \mathrm{m}$ and mean width equal $0.95 \mu \mathrm{m}$ ) of the muscle cells appeared just beneath the sarcolemma. They were oval or spindle shaped in appearance with predominant heterochromatin. Adjacent to the inner nuclear membrane, the heterochromatin appeared as dense aggregates surrounded by a regular nuclear envelope. The envelope appeared perforated by nuclear pores (Figure 22). The mitochondria appeared oval in shape (their mean length was found to be equal $1.6 \mu \mathrm{m}$ and mean width was found to be equal $1.3 \mu \mathrm{m}$ ) and were clearly visible in the sarcoplasm adjacent to the nuclei. Glycogen granules reserves were sparse in muscle cell and a few small lipid droplets were found in some of the myocytes. Sarcoplasmic reticulum vesicles appeared to be distributed among myofibrils (Figure 23).

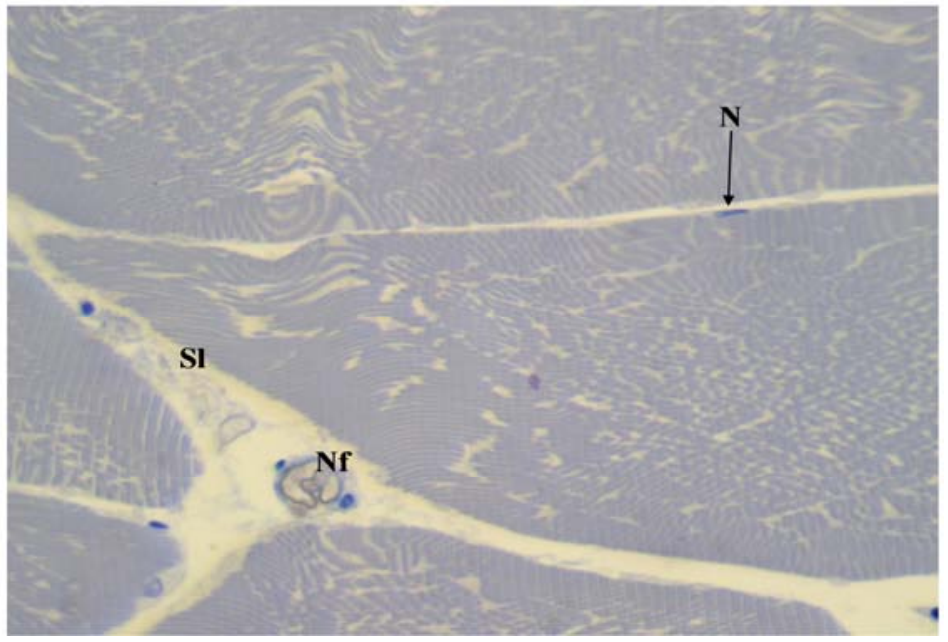

Figure 20. Light micrograph. Semithin section of muscle of "Siganus rivulatus" collected from Matrouh coast (control area). Demonstrating, normal muscle cells architecture, nerve fiber (Nf) in perimycium, sarcolemma (Sl), nucleus (N) small in size located peripherally [Glutaraldehyde fixed-Os $\mathrm{O}_{4}$ post fixedtoulidine blue-stained preparation $X, 1500]$.

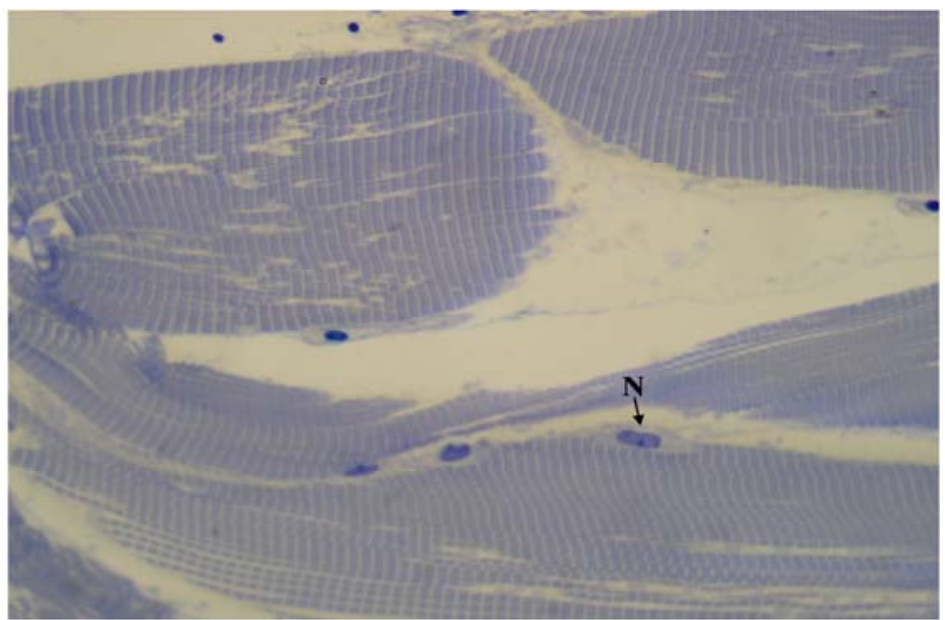

Figure 21. Light micrograph. Semithin section of muscle of "Siganus rivulatus" collected from Matrouh coast (control area). Illustrating, normal muscle architicure, muscle fibers with peripherally distributed nuclei (N) [Glutaraldehyde fixed-Os $\mathrm{O}_{4}$ post fixed-toulidine blue-stained preparation $\mathrm{X}$, 1500]. 


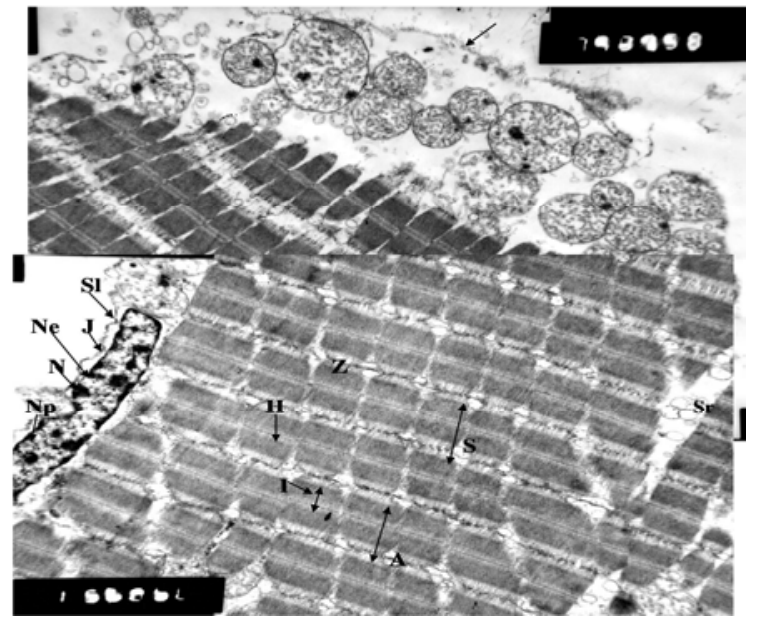

Figure 22. Electron micrograph. Longitudinal section of muscle of "Siganus rivulatus" collected from Matrouh coast (control area). Showing, regular striations, part of sarcolemma (Sl), with junctional folds $(\mathrm{J})$, Part of the nucleus (N), with normal heterochromatin (Hc) distribution, regular nuclear envelope ( $\mathrm{Ne}$ ) and nuclear pore (Np), sacroplasmic reticulum $(\mathrm{Sr})$, obvious isotropic band (I), Z-line (Z), sacromere length (S), Anisotropic band (A), less distinct $\mathrm{H}$-zone $(\mathrm{H})$ [Glutaraldehyde fixed- $\mathrm{OsO}_{4}$ post fixed- uranyl acetate-lead citrate stained preparation X, 10500].

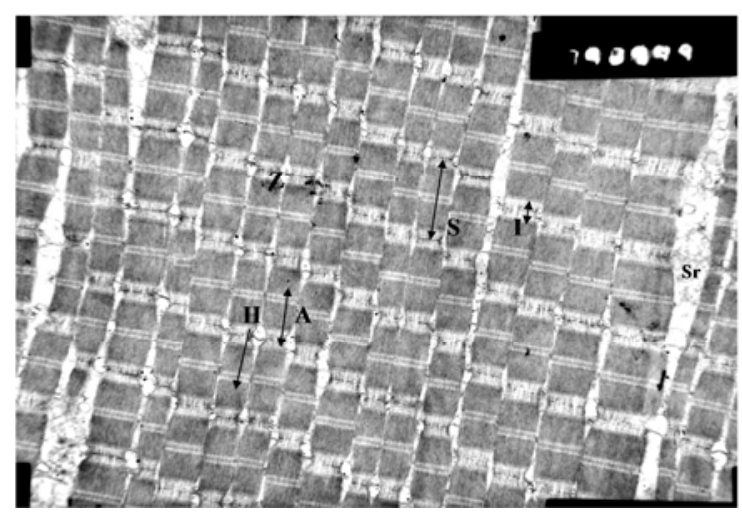

Figure 23. Electron micrograph. Longitudinal section of muscle of "Siganus rivulatus" collected from Matrouh coast (control area). Demonstrating, regular striations, sarcoplasmic reticulum (Sr), obvious isotropic band (I), Zline (Z), sacromere length (S), anisotropic band (A), less distinct H-zone (H) ) [Glutaraldehyde fixed- $\mathrm{OsO}_{4}$ post fixed-uranyl acetate -lead citrate stained preparation $X, 10500]$.

c. Structure of muscle specimens of Siganus rivulatus from El-Mex Bay

Light micrograph of muscle fibers of Siganus rivulatus from El-Mex bay showed similar general appearance. The muscle cells were enveloped by a delicate sheath of connective tissue, the endomysium, and were connected to nerve side branches and blood capillaries (Figure 24). Our measurement based on light micrographs showed that the muscle cell have mean thickness equal about $17.5 \mu \mathrm{m}$. Data analysis using student t-test exhibit that there is a highly significant decrease in the muscle cell thickness in the test area comparing to that of control area at $p<0.05$. The sarcolemma was identified as a regular out line enclosing the muscle fiber having numerous folds, termed junctional folds. The muscle fibers were arranged in a strictly ordered cross- striation of alternating brands of light and dark material (Figure 24).

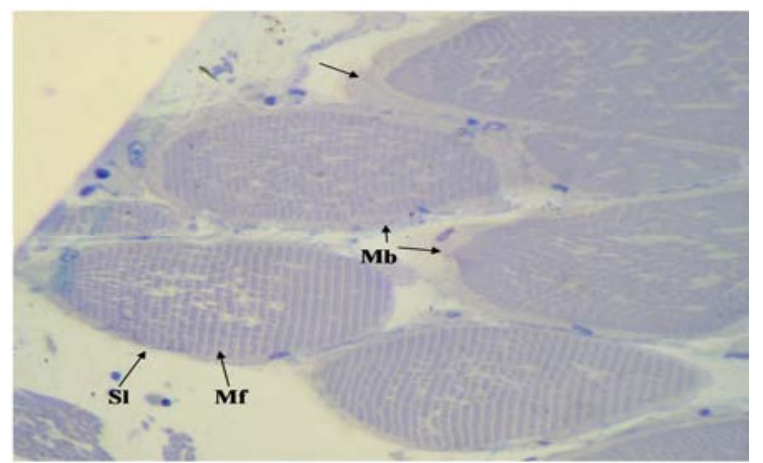

Figure 24. Light micrograph. Semithin section of longitudinal section of muscle of fish "Siganus rivulatus" collected from El-Mex Bay (test area). Showing, muscle bundle (Mb), muscle fibres (Mf), endomysium (thin arrow), sarcolemma (Sl) [Glutaraldehyde fixed-O $\mathrm{SO}_{4}$ post fixed-toulidine bluestained preparation $X, 1500]$.

Electron microscopic preparations showed that the muscle fibers of "Siganus rivulatus"were composed of sarcoplasm in which longitudinal arrays of myofibrils were observed. The center of each dark (A-band or actin) was occupied by a pale area known as H-zone (Hensen,s Zone) which is bisected by an additional thin striation known M-line (Mittelsheibe). However, light band (I-band or myosin) was very difficult to distinguish. A thin dark line, known as a Z-line (Zwischenscheibe) bisected the I-band which was relatively thick and distinguished by its density. The average length of the sarcomere was found to be equal $1.58 \mu \mathrm{m}$. The average length of A-bands was found to be $1.1 \mu \mathrm{m}$. while the I-bands was found to be $0.45 \mu \mathrm{m}$ and the H-zone was found to be 0.16 $\mu \mathrm{m}$ (Figures $25 \& 26$ ). Data analysis using student t-test revealed that there is insignificant difference in this measurement between the test area and control area at $\mathrm{p}<0.05$. Electron microscopic preparations of the "Siganus rivulatus" muscle collected from test area showed that muscle fibers possessed highly altered nuclei with mean length equal $3.3 \mu \mathrm{m}$ and mean width equal $1.04 \mu \mathrm{m}$, with large size nucleoli, with irregular and disrupted nuclear envelope, with dilated nuclear pores. Data analysis using student t-test exhibit that there is a highly significant decrease in the nuclear length in the test area comparing to that of control area but there is insignificant difference in the nucleus width between the two area at $p<0.05$. The mitochondria appeared small in size, their mean length equal $0.9 \mu \mathrm{m}$ and mean width equal $0.71 \mu \mathrm{m}$ with dense matrix. In these preparations the sub-sacrolemma mitochondria appeared disrupted and lysis in the cytoplasm (Figures 25, 26). Data analysis using student t-test exhibit that there is a highly significant decrease in the mitochondria length and width in the test area comparing to that of control area at $p<0.05$. They possessed slightly electron dense matrics and well preserved tubular cristae that traversed the whole width of the organelle (Figures 26, 27). Glycogen reserves were sparse in muscle cell and a few small lipid droplets were found in some of the myocytes. 
Sarcoplasmic reticulum vesicles appeared to be distributed among myofibrils (Figure 26).

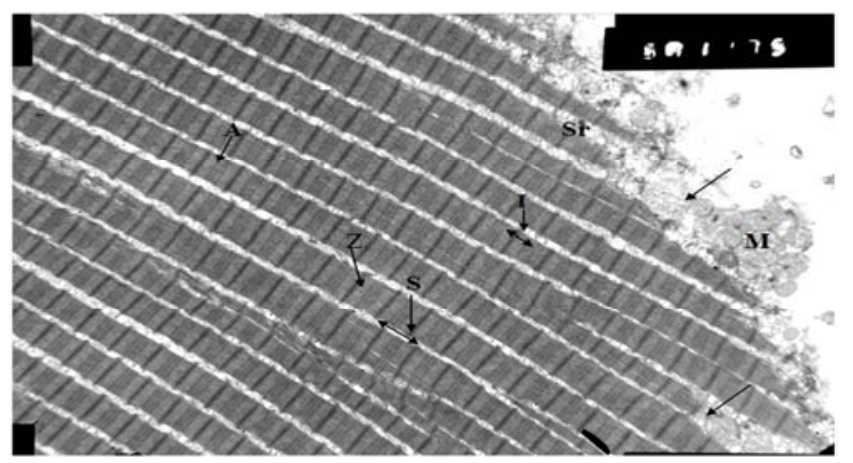

Figure 25. Electron micrograph. Longitudinal section of muscle of "Siganus rivulatus" collected from El-Mex Bay (test area). Showing, sarcoplasmic reticulum (Sr), mitochodria (M) with different sizes and with altered structure, obvious isotropic band (I), Z-line (Z), sacromere length (S), anisotropic band (A), less distinct $H$-zone (H), disrupted sarcolemma (arrow) [Glutaraldehyde fixed- $\mathrm{OsO}_{4}$ postfixed-uranyl acetate - lead citrate stained preparation $X, 7500]$.

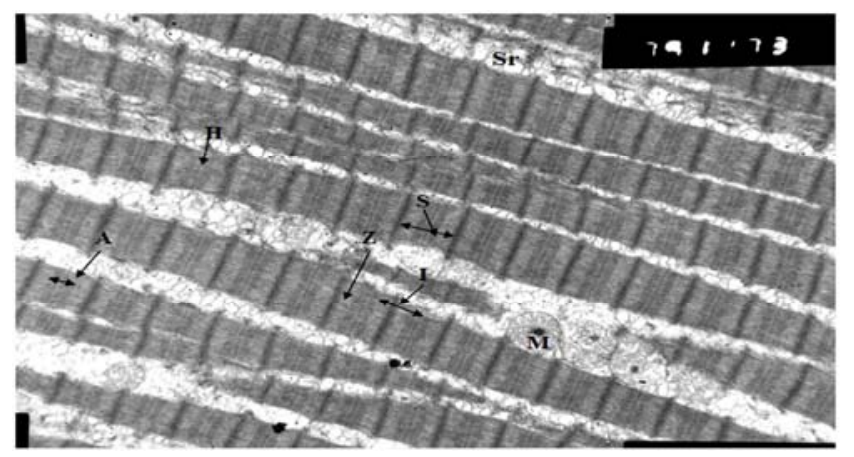

Figure 26. Electron micrograph. Longitudinal section of muscle of "Siganus rivulatus" collected from El-Mex Bay (test area). Showing, sarcoplasmic reticulum (Sr), mitochondria $(M)$ with large size located in between myofibrils, obvious isotropic band (I), Z-line (Z), sacromere length (S), anisotropic band (A), less distinct $\mathrm{H}$-zone $(\mathrm{H})$ [Glutaraldehyde fixed- $\mathrm{OsO}_{4}$ post fixed-uranyl acetate-lead citrate stained preparation X, 10500].

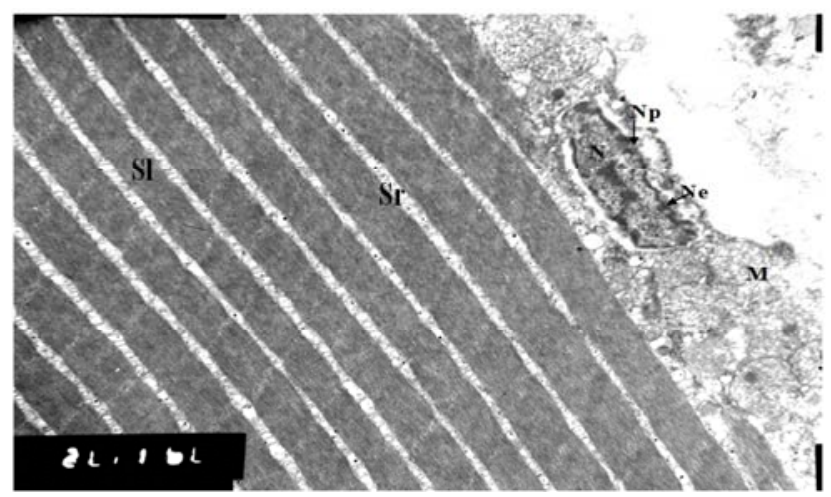

Figure 27. Electron micrograph. Longitudinal section of muscle of "Siganus rivulatus" collected from El-Mex Bay (test area). Showing, part of sarcolemma (Sl), highly altered nucleus $(N)$ with decreased chromatin, with irregular nuclear envelope (Ne), with dilated nuclear pores (Np), subsacrolemma mitochondria (M) appeared disrupted, lysis in the cytoplasm, it is very difficult to distinguish A band, I band, sacromere length, no obvious sarcoplasmic reticulum (Sr) [Glutaraldehyde fixed- $\mathrm{OsO}_{4}$ post fixed-uranyl acetate-lead citrate stained preparation X, 10500].

\section{Conclusion}

The oxidative stress and antioxidant response as well as ultrastructural changes of both liver and muscle tissues of Siganus rivulatus collected from two different areas in the north-western Mediterranean coast of Egypt have been investigated. The present study revealed that the induction of antioxidant systems in response to oxidative stress and the increase in lipid peroxidation in fish collected from the polluted area were good indicators for the pollution load. In the meantime, the ultrastructural changes served as a biomarker of stress in aquatic environment and the chemical pollution is capable of inducing morphological alteration in liver of fish collected from polluted area.

\section{References}

[1] Wahby SD, Shriadach MA, (1984). The effect of sewage discharge on some chemical characteristics of seawater. VII Journees Etud Pollutions, Lvcerene. CIESM, 81-90.

[2] Shriadah MA (1992). Trace elements concentration in fish samples from Alexandria region. Bull. High Inst Public Health, XXII (3),437- 444.

[3] Shriadah MA, Tayel FR, (1992).Impacts of industrial, sewage and agricultural effluents on Lake Edku and Abu-Qir Bay. Bull. Fac. Sci., Alex. Univ., 32(A), 103-155.

[4] Emara HI, Shriadah MA, Maoustafa TH and El- Deek MS (1992). Effects of Sewage and Industrial Wastes on the Chemical Characterstics of the Eastern harbor and El- Max Bay Waters of Alexandria, Egypt. Science of the Total Environment, 773-784.

[5] Abdel Fatah L, Fahmy MA and Shriadah MA (2003). Zn, Cu, $\mathrm{Cd}, \mathrm{Pb}$ and $\mathrm{Hg}$ in the Egyptian Coastal Sediments along the Mediterranean Sea Ass. Mod. \&Simul. Enterpr. (AMSE) (France), 64 (3), 55-69.

[6] Shriadah MA, Hassan S (2005). Distribution and Speciation of Some Heavy Metals in an Industrial Waste Water Discharge Area, Egypt. Ass. Mod. \& Simul. Enterpr. (AMSE), Mod. C., (France), 66 (5), 31-42.

[7] Shriadah MA, Said TO, Younis AM, Farag RS, (2006). Speciation of Organotin Compounds in Sediments of semiclosed areas along the Mediterranean Coast of Alexandria. Chemistry and Ecology. 22 (5), 395-404.

[8] Shakweer L, Shriadah MA, Fahmy MA and Abdel Fattah L (2006). Distributions and concentrations of trace elements along the Mediterranean coastal water of Egypt. Egyptian Journal of Aquatic Research, 32(2), 95-127.

[9] Abdel Ghani SA, Shobier AH and Shreadah MA (2013). Assessment of Arsenic and Vanadium Pollution in Surface Sediments of the Egyptian Mediterranean Coast. Journal of Environmental Technology and Management, 16 (1/2), P: 82101.

[10] Shriadah MA, Abdel Ghani S, (2007). Impacts of Land Based Sources on Water Quality of Abu - Qir Drain, Egypt. Proceeding of $8^{\text {th }}$ International Conference on the Mediterranean Coastal Environment. MEDCOAST 07. E. Ozhan (Editor), 13-17 November 2007, Alexandria, Egypt. 863 - 872. 
[11] Shreadah MA, Said TO, Abd El Ghani SA, Ahmed AM, (2008). Alkyllead andAlkyltin Species in different fishes collected from the Suez Gulf, Egypt. Proceedings of the $2^{\text {nd }}$ International Conference on Aquatic Res, Egyptian J. Aqu. Res., 34(4), 64-73.

[12] Shreadah MA, Said TO, Abdel Ghani SA, Ahmed AM, (2011). Distribution of Different Organotin and Organolead Compounds in Sediment of Suez Gulf. Journal of Environmental Protection, 2(5), 545- 554.

[13] Shobier AH, Abdel Ghani SA and Shreadah MA (2011). Distribution of Total Mercury in Sediments of Four SemiEnclosed Basins along the Mediterranean Coast of Alexandria. Egyptian J. Aqu. Res, 37 (1), 1-11.

[14] Abdel Salam S, El Zokm G, Shobier A, Othman T, Shreadah MA, (2013). Metal Pollution in Surface Sediments of Abu Qir Bay and the Eastern Harbour of Alexandria, Egypt. Egyptian J. Aqu. Res., 39. 1-12.

[15] Shreadah MA, Masoud MS, Khattab AM, El Zokm G, (2014a). Impacts of different Drains on the Seawater Quality of El-Mex Bay (Alexandria, Egypt). Journal of Ecology and the Natural Environment, 8 (8), 287-303.

[16] Shreadah MA, Abdel Fattah L and Fahmy MA (2015). Heavy metals in some fish species and bivalves from the Mediterranean coast of Egypt. Journal of Environmental protection, 6(1), 1-9. 74 .

[17] Leung HM, Leung AOW, Wang HS, Maa K, Liang Y, Ho KC, Cheun g KC, Tohidi F, Yung KKL, (2014). Assessment of heavy metalsLmetalloid ( $\mathrm{As}, \mathrm{Pb}, \mathrm{Cd}, \mathrm{Ni}, \mathrm{Zn}, \mathrm{Cr}, \mathrm{Cu}, \mathrm{Mn}$ ) concentrations in edible fish species tissue in the Pearl River Delta (PRD), China, Marine Pollution Bulletin, 78:235-245.

[18] Abdel-Moneim NM, Abdel-Moaguid NE, El-Sikaily AM, Zaki MG, Shreadah MA (2018). "Biomarkers and Ultrastructural Evaluation of Marine Pollution by Polycyclic Aromatic Hydrocarbons. J. Environ. Protection, 1283-1304.

[19] Fathy SA, Abdel Hamid FF, Shreadah MA, Mohamed LA and El- Gazar MG (2012a). Effect of Some Environmental Pollutants on Enzymatic and Total Antioxidant Activities in Tilapia Niloticus. Blue Biotechnology Journal (BBJ), 1 (3), 433-443.

[20] Fathy SA, Abdel Hamid FF, Shreadah MA, Mohamed LA and El- Gazar MG (2012b). Application of Principal Component Analysis for Developing Water Quality Index for Selected Coastal Areas of Alexandria Egypt. Recourses and Environment Journal, 2 (6), 297-305.

[21] Said TO, Moselhy KME, Rashad AM, Shreadah MA (2008). Organochlorine Contaminants in Water, Sediment and Fish of Lake Burullus, Egyptian Mediterranean Sea. Bull Environ. Contam. Toxicol., 81(2), 136-146.

[22] Shreadah MA, Said TO, Othman IM, Fathallah EMI and Mahmoud ME, (2012). Polychlorinated biphenyls and chlorinated pesticides in Sediments along the Semi-closed Areas of Alexandria, Egypt, Journal of Environmental Protection (JEP), 3(2), 141- 149.

[23] Shreadah MA, Said TO, Othman IM, Fathallah EMI and Mahmoud ME, (2014b). Organo- chlorines in Seawater from Egyptian Mediterranean Coast of Alexandria. Development in Analytical Chemistry, 1, 19-24.

[24] Tayel FR, Shriadah MA (1991). Effect of pollution by hydrogen sulphides on certain aquatic organisms. Bull. High Inst. Public Health, XXI(4), P: 801-813.

[25] Shriadah MA and Emara HI (1992). Iron, Manganese, Nickel, Lead, and Cadmium in fish and crustacea from the Eastern harbor and El-Mex Bay of Alexandria. Bull. High Inst. Public Health, XXII(3), P: 515- 525.

[26] Tayel FR, Fahmy MA and Shriadah MA (1996). Studies on the physicochemical characteristics of Mex Bay and New Dekhaila harbor waters of Alexandria, Egypt. Bull. Nat. Inst. Oceanogr. \& Fish., A.R.E., Vol. 22,P: 1-18.

[27] Metts B, Hopkins W, and Nestor J,( 2005). "Interaction of an insecticide with larval density in pond-breeding salamanders (Ambystoma)". Ecological Applications. 11(2): 464-479.

[28] Said TO, Farag RS, Younis AM, Shreadah MA, (2006). Organotin Species in Fish and Bivalves samples collected from the Egyptian Mediterranean Coast of Alexandria, Egypt.Bull. Environ. Contam. Toxicol.,Vol . 77 (3), P: 451458.

[29] Shreadah MA, Abdel Fattah L and Fahmy MA (2015). Heavy metals in some fish species and bivalves from the Mediterranean coast of Egypt. Journal of Environmental protection, $6(1), 1-9$.

[30] Sarkar A, Ray D, Shrivastava A, Sarker S, (2006). "Molecular biomarkers: their significance and application in marine pollution monitoring”. Ecotoxicology. 15:333-340.

[31] Mohamed B, Bouraoui Z, Ghedira J, Clearandeau C, Jebali J, Boussetta H, (2009)."Seasonal variation of oxidative stress biomarkers in clams Ruditapes decussates sampled from Tunisian coastal areas". environment monitoring assess.155:119-128.

[32] Emara HI, and Shriadah MA (1991). Manganese, Iron, Cobalt, Nickel, and Zinc in the Eastern harbor and El-MexBey Waters (Alexandria). Inter. Proc. Symp. Mar. Chem. In the Arab Region, Suez, April, 1991, P: 97-112.

[33] Shriadah, MA and Emara, HI (1991). The distribution of Chromium, Copper, Cadmium, and Lead in areas of multipolluting factors of Alexandria. Inter. Proc. Symp. Mar. Chem. In the Arab Region, Suez, April, 1991, 30-50.

[34] Shriadah MA and Emara HI (1992). Iron, Manganese, Nickel, Lead, and Cadmium in fish and crustacea from the Eastern harbor and El-Mex Bay of Alexandria. Bull. High Inst. Public Health, XXII(3), P: 515- 525.

[35] Emara HI, Shriadah MA, Maoustafa TH and El- Deek MS (1992). Effects of Sewage and Industrial Wastes on the Chemical Characterstics of the Eastern harbor and El- Max Bay Waters of Alexandria, Egypt. Science of the Total Environment, 773-784.

[36] Said MA, El-Deek MS, Mamoud TH and Shriadah MA (1994). Effect of pollution on the hydrochemical characteristics of different water types in El-Mex Bay area west of Alexandria, Egypt. ActaAdriat. 34 (1/2), 9-19.

[37] Fahmy MA, Tayel FR and Shriadah MA (1995). Effect of pollution on the water quality of Mex Bay and Dekhaila harbor of Alexandria. 1st Int. Conf. on present and future technology of navigation and marine science of Mediterranean and the Red Sea, 29-31 October 1995, El- Mahrousa, Alex., Egypt. 
[38] Tayel FR, Fahmy MA and Shriadah MA(1996). Studies on the physicochemical characteristics of Mex Bay and New Dekhaila harbor waters of Alexandria, Egypt. Bull. Nat. Inst. Oceanogr. \& Fish., A.R.E., 22, 1-18.

[39] Shriadah MA, Emara HI,(1996). Heavy metals (Iron, manganese, nickel, Cadmium, and Lead) in the sediments from the Eastern harbor and El-Mex Bay of Alexandria, Egypt. Proc. $6^{\text {th }}$ Int. Symp. Environ. Prot. Is a must, P: 916927, Alexandria, 21-23 May, Egypt.

[40] Fahmy MA, Tayel FR, Shriadah MA, (1997). Spatial and seasonal variations of dissolved trace metals in two contaminated basins of the coastal Mediterranean Sea, Alexandria, Egypt. Bull. Fac. Sci., Alex. Univ., 37(2), 187198.

[41] Shreadah MA, Masoud MS, Khattab AM, El Zokm G, (2014a). Impacts of different Drains on the Seawater Quality of El-Mex Bay (Alexandria, Egypt). Journal of Ecology and the Natural Environment, Vol. 8 (8), pp.:287-303.

[42] Jangaard P, Brockerhoff H, Burgher R, Hoyle R, (1967). "Seasonal changes in general condition and lipid content of cod from inshore waters". J. Fish. Res. Board Can. 24: 607612.

[43] UNEP/IOC/IAEA, (1991). "Sampling of selected marine organisms and sample preparation for the analysis of chlorinated hydrocarbons". Reference methods of marine pollution studies no.12.revision 2.Nairobi. United Nations Environment programme. 17.

[44] Habig WH, Pabst MJ, Jokoby WB, (1974). "Glutathione 5transferases. The first enzymatic step in mercapturic acid formation". J. Biol. Chem. 249:7130-7139.

[45] Beutler E, Duron O, Kelly BM, (1963). "Improved method for the determination of blood glutathione". J. Lab Clin. Med. 61: 882-888.

[46] Reynolds E (1963). "The use of lead citrate at high $\mathrm{pH}$ as an electron-opaque stain in electron microscopy". J. Cell Biol. 17:208-212.

[47] Said TO, Shreadah MA, Mansour MA, Mohamed MA, ElSharkawi, FM (2017). "OCPs, PCBs and THCs in Sparus auratus Species from the Egyptian Mediterranean Coast". Open Journal of Marine Science, 7(2), 317-326.

[48] Abd El Moneam NM, Shreadah MA, Al-Assar SA, and NabilAdam A (2017). Protective role of antioxidant capacity of Hyrtios aff. Erectus sponge extract against mixture of Persistent organic pollutant (POPs)-induced hepatic toxicity in liver mice: Biomarkers and Ultra-structural study. Environmental Science and Pollution Research, 24(1), 2206122072DOI: $10.1007 / \mathrm{s} 11356-017-9805-8$.

[49] Boonyatumanond R, Wattayakorn G, Amano A, Inouchi Y, Takada H, (2007). "Reconstruction of pollution history of organic contaminants in the upper Gulf of Thailand by using sediment cores: First report from Tropical Asia Core (TACO) project". Marine Pollution Bulletin. doi: 10.1016/j.marpolbul.2006.12.007.

[50] Abd El Moneam NM, Shreadah MA, Al-Assar SA, De Voogd, NJ, Nabiel-Adam, A (2018).'Hepatoprotective effect of Red Sea sponge extract against the toxicity of a real-life mixture of persistent organic pollutants". Biotechnology \& Biotechnological Equipment 32 (3), 734-743
[51] Said O, Abdel Fattah M, (2005)."Distribution of chlorinated pesticides in surface water and fish of el temsah and bitter lakes, suez canal". egyptian journal of aquatic research. 31, 200-212.

[52] Kannan K, Tanabe S, Tastsukawa R, (1995). "Geographical distribution and accumulation features of organochlorine residues in fish in tropical Asia and Ocean”. Environmental Science and Technology. 29: 2673-2683.

[53] GESAMP, (1993).“Impact of Oil and Related Chemicals and Wastes on the Marine Environment". Rep. Stud, GESAMP (50): $180 \mathrm{pp}$.

[54] Havelkova M, Blahova J, Kroupova H, Randak T, Leontovycova I, Grabic R, Pospisil R, Svobodova Z, (2008). "Biomarkers of Contaminant Exposure in Chub (LeuciscuscephalusL.) Biomonitoring of Major Rivers in the Czech Republic". Health and Toxicology, Czech Republic. 8: 2589-2603.

[55] Akcha F, Izuel C, Venier P, Budzinski H, Burgeot T, Narbonne JF (2000) Enzymatic biomarker measurement and study of DNA adduct formation in benzo[a] pyrene contaminated mussels, Mytilus galloprovincialis. Aquat Toxic, 49: 269-287.

[56] [56] Regoli F, Gorbi S, Frenzilli G, Nigro M, Corsi I, Focardi S, Winston GW, (2002). "Oxidative stress in ecotoxicology: from the analysis of individual antioxidants to a more integrated approach". Marine Environmental Research. 54: 419-423.

[57] Solé M, Buet A, Ortiz L, Maynou F, Bayona JM, Albaigés J, (2007). "Biochemical responses in mussels exposed to the water-accommodated fraction of the "Prestige" fuel oil".Scientia Marina. 71: 373-382.

[58] Güll S, Belge-Kurutas E, Yildiz E, Sahan A, Doran F, (2004). "Pollution correlated modifications of liver antioxidant system and histopathology of fish (Cyprinidae) living in Seyhan Dam Lake, Turkey”. Environ, Int. 30: 605-609.

[59] Zhen Y, Aili J, (2011). "Evaluation of oxidative stress responses and neurotoxicity potential of methamidophos in Mytilusedulis". Advanced materials research. 795-801.

[60] Kurutas E B, Sahan A, Altun T,(2009). "Oxidative stress biomarkers in liver and gill tissues of spotted barb (CapoetabarroisiLortet, 1894) living in theriver Ceyhan, Adana, Turkey". Turk. J. Biol., 33: 275-282.

[61] Lesser MP, (2010). "Survivorship, oxidative stress, and DNA damage of sea urchin (Strongylocentrotusdroebachiensis) embryos and larvae exposed to ultraviolet radiation (290-400 $\mathrm{nm})$ in the Gulf of Maine". Photochemistry and Photobiology. 86: $382-388$.

[62] Shahbudin S, Deny S, Zakirun AM, Haziyamin TA, Akbar John B, Taher M, (2011). "Antioxidant properties of Soft Coral Dendronephthyasp". International journal of pharmacology. 7 (2): 263-267.

[63] Ahmad I, Pacheco M, Santos MA, (2004). "Enzymatic and non-enzymatic antioxidants as an adaptation to phagocyteinduced damage in Anguilla anguillaL following in situ harbor water exposure". Ecotoxicology and Environmental Safety. 57: 290-302.

[64] Santos MA, Pacheco M, Ahmad I, (2004). "Anguilla anguillaL. antioxidants responses to in situ bleached kraft pulp mill effluent outlet exposure". Environment International. 30: 301-308. 
[65] Ahmad I, Oliveira M, Pacheco M, Santos MA, (2005). "Anguilla anguillaL. oxidative stress biomarkers responses to copper exposure with or without Bnaphthoflavonepreexposure".Chemosphere. 61: 267-275.

[66] Siroka Z, Krijt J, Randak T, Svobodova Z, Peskova G, Fuksa J, Hajslova J, Jarkovsky J, Janska M, (2005). "Organic pollutant contamination of the River Elbe as assessed by biochemical markers". Acta Vet, Brno. 74: 293-303.

[67] Rathod V and Balkrishna PA, (2011). "Lipid peroxide, glutathione and glutathione-dependent enzyme (GST) in mixed zooplankton from the North-West Coast of India: Implication for the use ofenvironmental monitoring". African Journal of Biotechnology, 10 (40): 7862-7867.
[68] Havelková M ,Randák T , Blahová J, Slatinská I, (2010). "Biochemical markers for the assessment of aquatic environment contamination”. InterdiscToxicol. 1(2): 169-181.

[69] Farombi E, Adelowo O, Ajimoko Y, (2007). "Biomarkers of Oxidative Stress and Heavy Metal Levels as Indicators of Environmental Pollution in African Cat Fish (Clariasgariepinus) from Nigeria Ogun River". Int. J. Environ. Res. Public Health. 4(2): 158-165. 